\title{
Responses of Vegetation and Ground Cover to Spraying a High Elevation, Big Sagebrush Watershed with 2,4-D
}

\author{
DAVID L. STURGES
}

\section{Abstract}

Total production of aboveground biomass on a 238-ha watershed was not affected when big sagebrush (Artemisia tridentata) was controlled by aerial application of $2,4-\mathrm{D}(2,4$-dichlorophenoxyacetic acid). Grass production increased in the 5 years following treatment, but forb production was not affected by treatment because forbs were in an early phenological stage when sprayed. Five years after treatment, there was a $37 \%$ decrease in bare ground, and a $29 \%$ and $61 \%$ increase in litter and grass cover, respectively, on the treated watershed compared to an adjacent untreated watershed.

A cost effective method of increasing the quantity of forage available for livestock on big sagebrush (Artemisia tridentata) rangeland involves application of 2,4-D (2,4-dichlorophenoxyacetic acid) to control shrub growth (Nielsen 1979, Kearl and Freeburn 1980, Schmisseur and Miller 1980). ${ }^{1}$ Spraying is feasible for sites that have valuable herbaceous species capable of fully utilizing site resources (Pechanec et al. 1965). Grass production commonly doubles or triples after treatment (Hyder and Sneva 1956, Hedrick et al. 1966, Tabler 1968, Schumaker and Hanson 1977, Sturges 1977, Miller et al. 1980). Forbs are adversely affected by 2,4-D, so that increases in grass productivity are partially offset by decreases in forb productivity (Blaisdell and Mueggler 1956, Laycock and Phillips 1968, Tabler 1968, Schumaker and Hanson 1977, Miller et al. 1980).

The influence of sagebrush control on ground cover characteristics has received little attention compared to changes in vegetation production. Basal area of grasses increased about one-third when big sagebrush was controlled by spraying or grubbing and most of the increase occurred the first year after treatment (Hyder and Sneva 1956). Reseeding two small sagebrush-dominated watersheds that had been depleted of herbaceous spccies, to beardless bluebunch wheatgrass (Agropyron inerme), greatly reduced the area of bare soil (Shown et al. 1972). The reduction in bare soil was believed influential in reducing surface runoff generated by summer rainstorms, and in reducing the sediment concentration of runoff water (Lusby 1979).

The objective of this study was to measure changes in vegetation production and composition, and changes in watershed ground cover characteristics on a watershed sprayed with 2,4-D to control big sagebrush. The study was part of a long-term paired watershed investigation, in which hydrologic and wildlife responses to spraying also were evaluated.

\section{Study Area}

The study was conducted at the Stratton Sagebrush Hydrology Study Area, in southcentral Wyoming, about $32 \mathrm{~km}$ west of Saratoga. Loco and Sane Creek watersheds, 663 ha and 238 ha, respectively, were utilized. The watersheds ranged between $2,340 \mathrm{~m}$ and

\footnotetext{
Author is with the Rocky Mountain Forest and Range Experiment Station, Laramie, Wyoming

The headquarters is in Fort Collins in cooperation with Colorado State University; research reported here was conducted at the Station's Research Work Unit in Laramie, in cooperation with the University of Wyoming. Portions of the research were supported by the Bureau of Land Management, U.S. Department of the Interior.

Manuscript accepted 11 June 1985.

This article reports research involving pesticides. It does not contain recommendations for their use, nor does it imply that the uses discussed here have been registered. All uses of pesticides must be registered by appropriate state and/or federal agencies before they can be recommended. Use all pesticides selectively and carefully; read and follow directions on the label.
}

2,470 $\mathrm{m}$ in elevation. Loco Creek flows easterly, and the watershed has primarily north and south exposures. Sane Creek drains in a southerly direction, and the watershed has east, south, and west exposures (Fig. 1). Perennial flow in Loco Creek begins at a spring about $1.6 \mathrm{~km}$ above the stream gage, while Sane Creek begins at a spring $45 \mathrm{~m}$ above the stream gage. The Loco Creek drainage remained in an undisturbed state throughout the study while the Sane Creek drainage was sprayed.

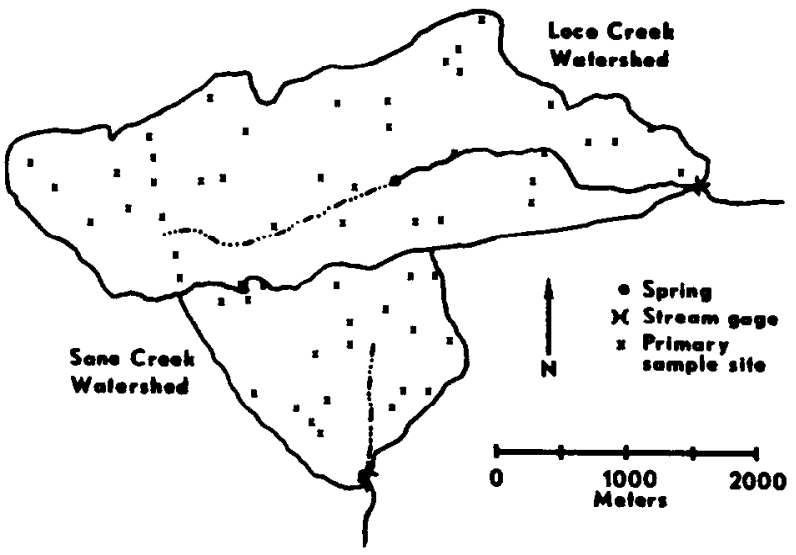

Fig. 1. The Stratton Sagebrush Hydrology Study Area. Vegetation and ground cover characteristics were sampled at 38 primary sampling locations on Loco Creek watershed and 20 primary sampling locations on Sane Creek watershed, indicated by an X.

Annual precipitation from 1969 through 1982 was $52.6 \mathrm{~cm}$. About $75 \%$ of precipitation fell as snow; summer rainfall (JuneSeptember) was $10.6 \mathrm{~cm}$. Average annual temperature was $2.7^{\circ} \mathrm{C}$; maximum daily temperatures were well below freezing from midNovember through March. Average monthly wind speed exceeded $5 \mathrm{~m} / \mathrm{s}$ between November and April. Wind speed was at a maximum in January, with a speed of $8.3 \mathrm{~m} / \mathrm{s}$, and fell to about $3.5 \mathrm{~m} / \mathrm{s}$ in July and August.

Soils developed in place from the Brown's Park Formation and are primarily Argic Cryoborolls. A and B horizons typically have a loam texture, but there are wide differences in profile development. The combined depth of $A$ and $B$ horizons of the Haggerty series located in areas of moderate snow accumulation extends to $1.2 \mathrm{~m}$. Areas of little snow accumulation typically have soils belonging to the Kimmons series where $A$ and $B$ horizons have a combined depth of $0.5 \mathrm{~m}$, or to the less well-developed Roxal series, where the A horizon is $15 \mathrm{~cm}$ deep and a $B$ horizon is lacking.

Mountain big sagebrush (A.t. ssp. vaseyana) up to $1 \mathrm{~m}$ tall characterizes areas of deeper soils, while Wyoming big sagebrush, (A.t. ssp. wyomingensis) or mixed stands of Wyoming big sagebrush and black sagebrush ( $A$. nova) indicate areas of shallow soil development. Herbaceous vegetation in mountain big sagebrush stands is composed primarily of grasses such as Idaho fescue (Festuca idahoensis), blue grass (Poa sp.), needlegrass (Stipa sp.) and sedge (Carex interior). June grass (Koeleria macrantha), bluebunch wheatgrass (Agropyron spicatum), and bottlebrush squirreltail (Sitanion hystrix) are typical of more xeric sites. Forbs are a minor vegetation component evident primarily in the spring. The more abundant forbs associated with mountain big sagebrush are 
silky lupine (Lupinus argenteus), buckwheat (Eriogonum ovalifolium), yarrow (Achillea millifolium ssp. lanulosa), and groundsel (Senecio integerrimus). The cushion plants, goldenweed (Haplopappus acaulis), sandwort (Arenaria hookeri) and phlox (Phlox sp.), are common on windswept upland and ridge sites.

The study site lies within a sheep allotment administered by the Bureau of Land Management, USDI. Sheep typically moved onto the Stratton area in late May and grazed 1 month, then returned for another 4 to 8 weeks of grazing in August. Vegetation utilization was light to moderate throughout the study. The treated watershed was deferred from grazing in the treatment year and for 2 years after treatment.

\section{Methods}

\section{Vegetation Sampling Network}

A two-stage sampling design was used to estimate watershed ground cover characteristics and vegetation production. Primary sample units consisted of square blocks $127 \mathrm{~m}$ on a side (1.6 ha). Thirty-eight primary units were randomly placed in Loco Creek watershed and 16 primary units were randomly placed in Sane Creek watershed. Subsequently, 4 additional units were added to the Sane Creek network to provide 20 primary sample units (Fig. 1). Five secondary locations were randomly selected within each primary unit for measuring vegetation production and ground cover.

\section{Ground Cover}

The 5 secondary locations within each primary sample unit served as the reference end for $30-\mathrm{m}$ long ground cover transects. Transects were oriented in a north-south direction, and the ends were permanently marked with pipe. A steel tape was stretched between the pipe at sagebrush canopy height and ground cover measurements were taken at 0.3 -m intervals along the tape (Fig. 2). Thus, 100 measurements of ground cover were made on each transect, which provided 500 values at each primary site.

Ground cover was determined using a brass rod tapered to a point on one end. The rod was $76 \mathrm{~cm}$ long and $4.7 \mathrm{~mm}$ in diameter and was lowered to the ground surface in a vertical plane with the aid of an attached bubble level (Fig. 2). Material encountered at the ground surface was classified as bare ground, rock, litter, erosion pavement, grass (including sedge), forb, cushion plant, sagebrush, or other shrub. Erosion pavement was defined as rocks smaller than $13 \mathrm{~cm}$ in maximum length. Only basal hits on the live and rooted portion of a plant were recorded as vegetation. Aerial hits on the sagebrush canopy were also recorded.

Analysis of the initial ground cover data collected in 1968 indicated that Loco and Sane Creek watersheds had similar characteristics for all parameters. Further, it was necessary to sample only about 20 primary sites to achieve a sampling precision within $20 \%$ of the mean at the $95 \%$ confidence level. Time and manpower constraints prevented annual measurements of ground cover on Loco and Sane Creek watersheds and a triannual sampling program was adopted. The 2 watersheds were considered to be a common population before treatment; therefore, sampling was conducted at randomly selected primary sites from both watersheds in 1971 and 1974. Watersheds were independently sampled after spraying, but ground cover measurements on Loco Creek watershed were made the year after measurements on Sane Creek watershed.

\section{Vegetation Productivity}

Pipe marking the ends of ground cover transects served as corners of permanent plots used for measuring aboveground biomass. Data collection began in 1968 and ended in 1981 and all primary sites on both watersheds were measured each year. Data were collected in late August or early September from 1968 to 1971, and in mid-July, as most grass species were maturing, in succeeding years.

An electronic capacitance meter that sampled a plot $30 \times 61 \mathrm{~cm}$
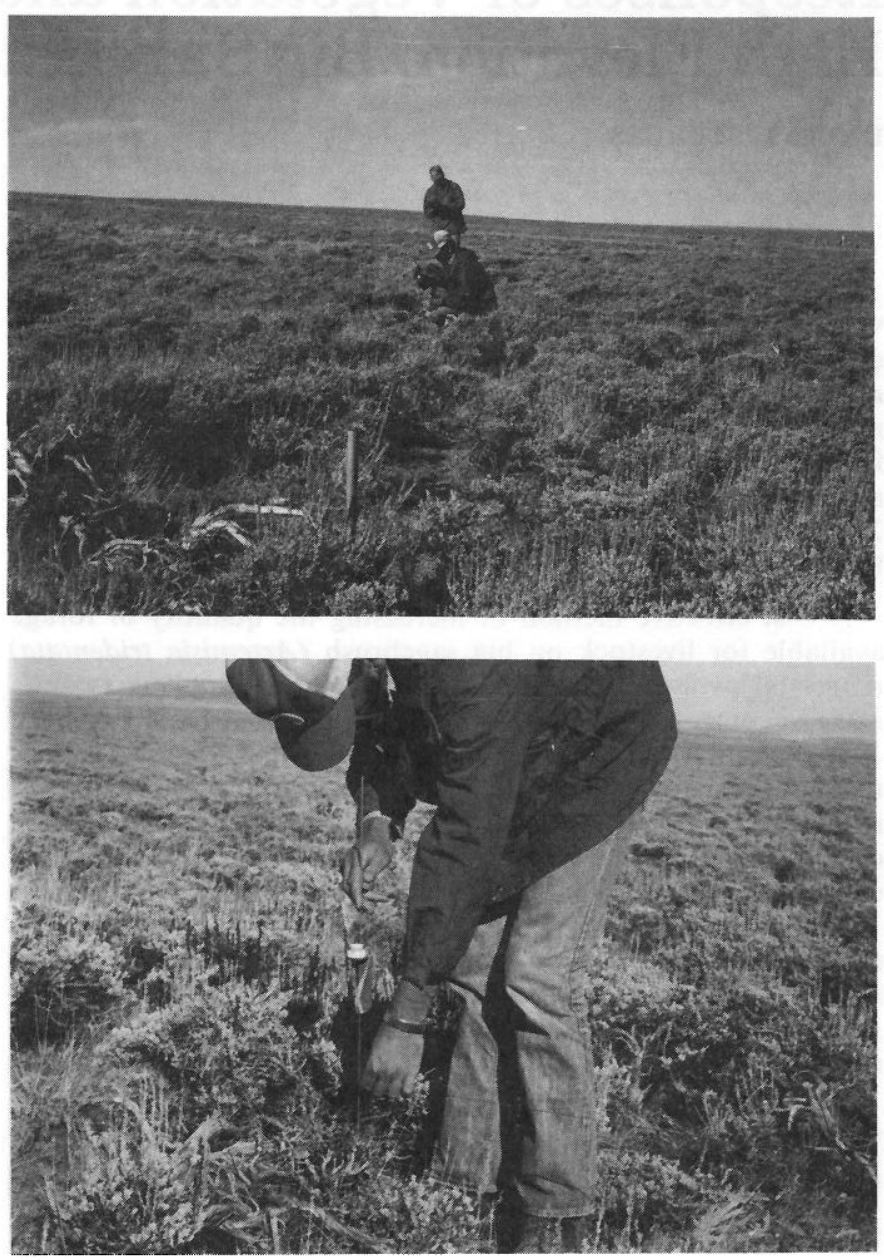

Fig. 2. Ground cover was measured at intervals of $0.3 \mathrm{~m}$ on transects $30 \mathrm{~m}$ in length (upper). A rod was lowered to the ground surface in a vertical plane with the aid of a bubble level to measure sagebrush canopy and ground cover characteristics (lower).

was used to measure total herbaceous biomass. Use of the meter was feasible because woody stem and trunk material of sagebrush contributes little to the capacitance value (Morris et al. 1976). Meter values were converted to vegetation weight by a regression relationship developed each year by double sampling. Data to establish the regression were gathered on 2 plots at each primary site. Plots were randomly located from the ends of ground cover transects. These plots were measured with the capacitance meter and then clipped at a $2.5-\mathrm{cm}$ stubble height. Thus, 12 locations were measured at each primary site each year to estimate production on a watershed.

The 3-dimensional technique described by Currie et al. (1973) and Morris et al. (1976) was utilized in clipping leaves and current annual twig growth of sagebrush as well as grasses and forbs. Vegetation subsequently was oven-dried at $105^{\circ} \mathrm{C}$ for 24 hours before weighing. Beginning in 1972, herbage on clipped plots was separated into sagebrush, grass, and forb categories to determine vegetation composition. Sedges were included with grasses because of morphological similarities and because of their minor importance as a vegetation component.

Analysis of data collected in 1968 indicated that the regression relationship between capacitance value and vegetation weight for Loco and Sane Creek watersheds belonged to a common population. Consequently, a single regression relationship developed from data collected on both watersheds was used to convert meter readings to herbage weight in years before spraying Sane Creek 
watershed. Thereafter, independent regression relationships were developed for the 2 watersheds.

\section{Sagebrush Density and Mortality}

Sagebrush density on Loco and Sane creek watersheds was determined 2 years before treatment by counting the number of plants rooted within belt transects $7.6 \mathrm{~m}$ long and $1.3 \mathrm{~m}$ wide $(0.001$ ha). One ground cover transect at each primary sampling unit was randomly selected for sampling. Belt transects originated at the south end of the ground cover transect and extended toward the north end.

The effect of spraying on individual sagebrush plants was assessed in July 1977, 14 months after Sane Creek watershed was sprayed. The same sampling procedure used to estimate sagebrush density before treatment was used, except that measurements were taken on 2 randomly selected transects at each primary sampling unit. The canopy area of individual sagebrush plants rooted within a belt transect was classified as 0-25\%, 26-50\%, 51-75\%, 76-99\%, or $100 \%$ dead. Average sagebrush mortality for each transect was calculated using the midpoint percentage value for each category of canopy damage and the number of plants within the category.

\section{Sagebrush Control on Sane Creek Watershed}

Sane Creek watershed was treated in 1976 to control sagebrush. Loco Creek watershed remained undisturbed throughout the study to provide a basis for assessing posttreatment changes on Sane Creek watershed. Standard Bureau of Land Management practices for aerial application of 2,4-D were followed. A buffer strip of unsprayed sagebrush that was $60 \mathrm{~m}$ in width and $300 \mathrm{~m}$ long was left immediately above the stream gage as wildlife habitat. The 2,4-D was applied in 28 liters of diesel oil/ha at an average rate of $2.2 \mathrm{~kg}$ acid-equivalent $/ \mathrm{ha}$. The maximum concentration of 2,4-D detected in water leaving Sane Creek watershed was 5 parts/billion at the completion of spraying (Schroeder and Sturges 1980). These levels are far below concentrations identified as toxic to fish (Juntunen and Norris 1972, Woodward and Mayer 1978). Herbicide was not detected in water 9 days after treatment.

\section{Statistical Analysis}

Mean values of ground cover and the associated $95 \%$ confidence interval were determined each year a watershed was sampled, utilizing analysis procedures for a two-stage sampling design. Analyses were based on the number of occurrences of each parameter on individual transects. There was a 1-year difference in measurement dates on Loco and Sane Creek watersheds in years after treatment, but mean ground cover values are believed representative of changes occurring on a watershed between the triannual sampling dates.

The analysis for total herbaceous production was based on data collected with the capacitance meter. Eight years of information (1968-1975) were available prior to spraying, and 5 years (1977-1981) were available after treatment. Information from 1976, when Sane Creek watershed was sprayed, was excluded from analysis. Data from clipped plots collected from 1972 to 1975 and 1977 to 1981 were used in the analysis of percentage composition data, and for analysis of sagebrush, grass, and forb production. Percentage composition data were transformed using the arcsin transformation before analysis.

Vegetation production and composition data were tested for statistical significance using a two factor analysis of variance (Green 1979). One factor compared watersheds, and the other factor compared pretreatment and posttreatment time periods. A significant interaction between watersheds and treatment time periods indicated that spraying altered the posttreatment average on Sane Creek watershed compared to the average for Loco Creek watershed. Significant annual differences in vegetation composition data were identified using a $t$ test. A 0.05 probability level was used to indicate statistical significance throughout this study.

\section{Results}

Sagebrush Mortality

In 1974 the density of sagebrush on Loco and Sane Creek watersheds was 36,800 and 35,600 plants/ha, respectively. Spraying reduced sagebrush canopy cover $77 \%$ of the Sane Creek drainage the year after treatment, and reduced the number of live plants $62 \%$ (Table 1).

Table 1. Canopy kill of individual sagebrush plants the year after Sane Creek watershed was sprayed with 2,4-D.

\begin{tabular}{cc}
\hline \hline Percent of plants & Percent canopy kill \\
\hline 16 & $0-25$ \\
7 & $26-50$ \\
9 & $51-75$ \\
6 & $76-99$ \\
62 & 100 \\
Avg. & 77 \\
\hline
\end{tabular}

\section{Vegetation Composition and Productivity}

The composition of vegetation on Loco and Sane Creek watersheds, as determined from clipped plots, was similar before treatment (Fig. 3). Sagebrush contributed about $60 \%$ of total vegetation production, grasses $25 \%$, and forbs the remaining $15 \%$. The response of vegetation on Sane Creek watershed to application of 2,4-D was typical of areas with adequate residual popula-

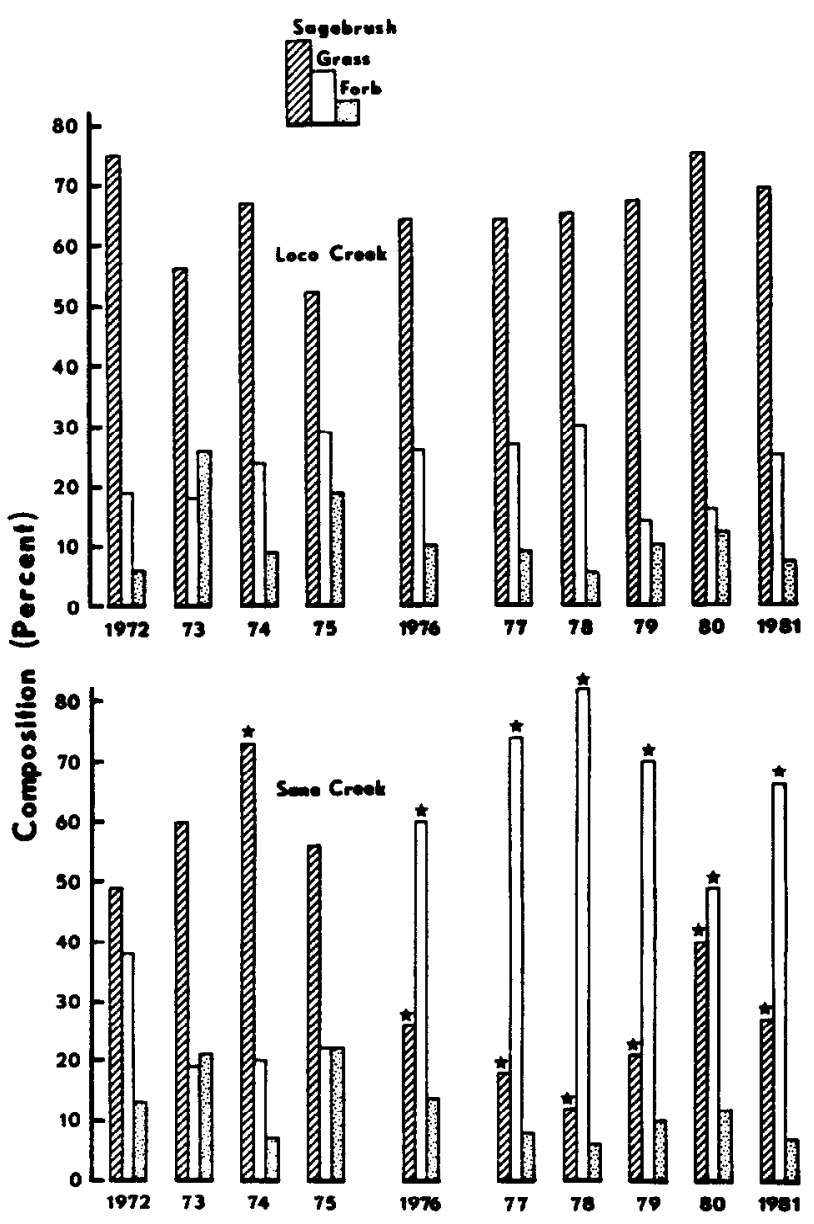

Fig. 3. Percentage composition of vegetation on Sane and Loco Creek watersheds. A star indicates that differences in composition between watersheds for the class of vegetation were significant at the 0.05 level of probability. 
tions of herbaceous species. Sagebrush contributed an average of $23 \%$ of total production in the 5 years after treatment, while grasses provided $68 \%$ of the total. Sagebrush and grass composition on the 2 watersheds were significantly different beginning in 1976, with treatment of Sane Creek watershed (Fig. 3). Percentage forb composition was not affected by spraying as it decreased $7 \%$ on both Sane and Loco Creek watersheds in years after treatment compared to the average pretreatment value.

Total annual production, including that of sagebrush, is shown in Table 2 for the 2 watersheds. Total production averaged 926 $\mathrm{kg} / \mathrm{ha}$ for Loco Creek watershed and $846 \mathrm{~kg} / \mathrm{ha}$ for Sane Creek watershed prior to spraying. Total production was approximately $100 \mathrm{~kg} / \mathrm{ha}$ less on both watersheds after spraying. Thus total

Table 2. Total annual herbaceous production and $95 \%$ confidence interval for Loco and Sane Creek watersheds, based on plots read with electronic capacitance meter.

\begin{tabular}{lcc}
\hline & \multicolumn{2}{c}{ Annual watershed production } \\
\cline { 2 - 3 } Year & Loco Creek & Sane Creek \\
\hline & \multicolumn{2}{c}{ Before treatment } \\
\cline { 2 - 3 } 1968 & $1,017 \pm 109$ & $680 \pm 116$ \\
1969 & $699 \pm 133$ & $827 \pm 136$ \\
1970 & $772 \pm 111$ & $790 \pm 124$ \\
1971 & $1,085 \pm 111$ & $1,174 \pm 128$ \\
1972 & $1,033 \pm 249$ & $568 \pm 94$ \\
1973 & $960 \pm 104$ & $765 \pm 141$ \\
1974 & $814 \pm 92$ & $921 \pm 212$ \\
1975 & $1,024 \pm 105$ & $1,044 \pm 128$ \\
Avg. & 926 & 846 \\
1976 & $907 \pm 97$ & $591 \pm 90$ \\
& & \\
1977 & & After treatment \\
1978 & $691 \pm 95$ & $819 \pm 66$ \\
1979 & $782 \pm 84$ & $668 \pm 68$ \\
1980 & $880 \pm 102$ & $663 \pm 93$ \\
1981 & $905 \pm 96$ & $859 \pm 92$ \\
Avg. & $923 \pm 83$ & 708 \\
\hline
\end{tabular}

herbaceous production was not significantly affected by treatment.

While total yield of herbaceous matter was unaffected by spraying, data from clipped plots indicated that the herbicide treatment increased the quantity of forage available for livestock. Grass production on Sane Creek watershed more than doubled after spraying on comparison to Loco Creek watershed, while sagebrush production decreased $71 \%$. Both changes were statistically significant (Table 3). Average forb productivity was almost identical on Loco and Sane Creek watersheds in years before and after spraying (Table 3).
Table 3. Herbaceous productivity of sagebrush, grass and forb vegetation on Loco and Sane Creek watersheds between 1972 and 1981, based on data from clipped plots.

\begin{tabular}{|c|c|c|c|c|c|c|}
\hline \multirow[b]{2}{*}{ Year } & \multicolumn{2}{|c|}{ Sagcbrush } & \multicolumn{2}{|c|}{ Grass } & \multicolumn{2}{|c|}{ Forb } \\
\hline & Loco & Sane & Loco & Sane & Loco & Sane \\
\hline & & & Before & atment & & \\
\hline $\begin{array}{l}1972 \\
1973 \\
1974 \\
1975\end{array}$ & $\begin{array}{l}645 \\
528 \\
515 \\
521 \\
\end{array}$ & $\begin{array}{l}245 \\
507 \\
818 \\
543 \\
\end{array}$ & $\begin{array}{l}168 \\
174 \\
188 \\
289 \\
\end{array}$ & $\begin{array}{l}193 \\
157 \\
230 \\
215 \\
\end{array}$ & $\begin{array}{r}49 \\
245 \\
73 \\
194 \\
\end{array}$ & $\begin{array}{r}63 \\
174 \\
82 \\
215 \\
\end{array}$ \\
\hline Avg. & $\overline{552}$ & 528 & $\overline{205}$ & 199 & $\overline{140}$ & 134 \\
\hline \multirow[t]{2}{*}{1976} & 550 & & 232 & & 84 & \\
\hline & & & After & tment & & \\
\hline $\begin{array}{l}1977 \\
1978 \\
1979 \\
1980 \\
1981\end{array}$ & $\begin{array}{l}400 \\
408 \\
515 \\
609 \\
556 \\
\end{array}$ & $\begin{array}{r}78 \\
87 \\
110 \\
244 \\
199 \\
\end{array}$ & $\begin{array}{l}166 \\
192 \\
180 \\
130 \\
204 \\
\end{array}$ & $\begin{array}{l}315 \\
585 \\
370 \\
293 \\
484 \\
\end{array}$ & $\begin{array}{l}55 \\
29 \\
72 \\
69 \\
48 \\
\end{array}$ & $\begin{array}{l}36 \\
45 \\
50 \\
74 \\
55 \\
\end{array}$ \\
\hline Avg. & $\overline{498}$ & $\overline{144^{*}}$ & $\overline{174}$ & $\overline{409^{*}}$ & 55 & 52 \\
\hline
\end{tabular}

*Value for Sane Creek significantly different from Loco Creek

\section{Ground Cover}

Average watershed ground cover values for each parameter are tabulated in Table 4. Average values for bare ground, litter, grass, and aerial sagebrush cover, with their associated confidence intervals, are shown in Figure 4. At the beginning of the study in 1968, no significant differences were present between watersheds for any ground cover parameter. As expected, aerial sagebrush cover on Sane Creek watershed significantly declined the year after treatment compared to Loco Creek watershed. Sagebrush canopy cover on Sane Creek watershed increased $68 \%$ between the first and fourth year after spraying. Cushion plants also were damaged by herbicide application, and their cover significantly decreased from the 1968 pretreatment level. Litter cover on the Sane Creek watershed increased significantly in years after spraying, while bare ground decreased.

Ground cover of grasses steadily declined between study initiation and treatment of the Sane Creek drainage. Data collected in 1977 on Sane Creek watershed and in 1978 on Loco Creek watershed, indicated that grass cover on both watersheds was about 50\% less than at the beginning of study. During the next 3 years, grass cover on Sane Creek watershed nearly doubled, but changed little on the untreated Loco Creek watershed (Fig. 4).

Hydrologic cover, taken as the sum of vegetation cover plus litter cover, is an indication of the potential for rainfall runoff; values throughout the study are tabulated in Table 4. Hydrologic cover values for Sane Creek watershed increased after spraying, but remained relatively constant on Loco Creek watershed. At the

Table 4. Ground cover and aerial sagebrush cover on Loco and Sane Creek watersheds from 1968-1981, and number of primary sites that were sampled.

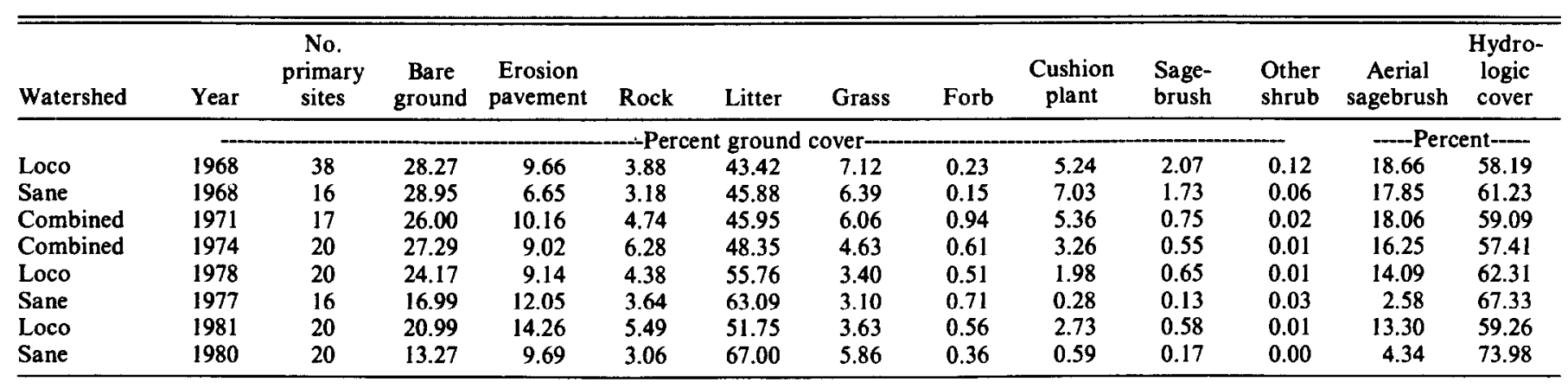



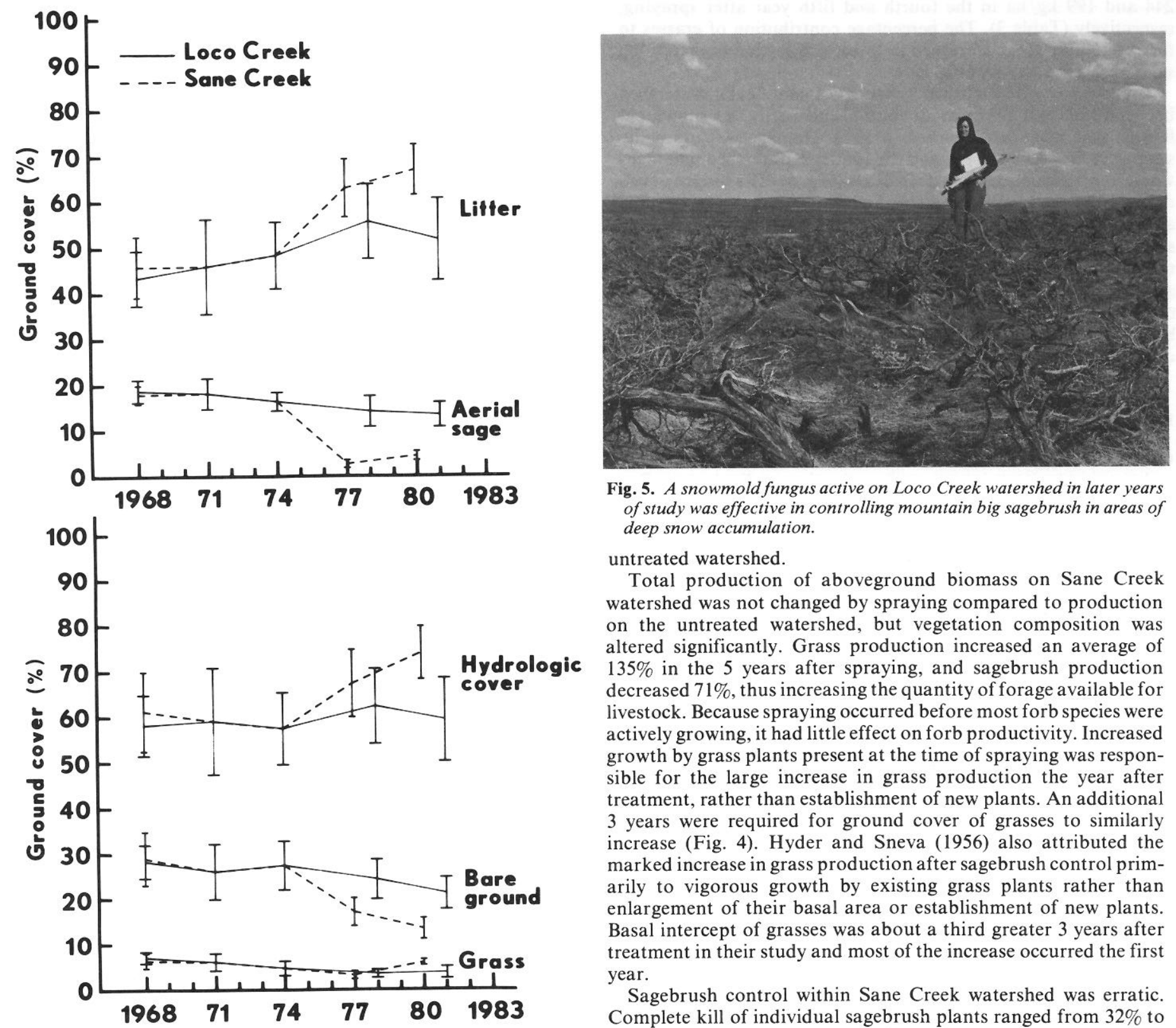

Fig. 4. Average ground cover and associated $95 \%$ confidence intervals for selected measurement parameters on Sane and Loco Creek watersheds from 1968-1981.

end of the study, differences between watersheds were significant at a 0.10 probability level.

Loco Creek watershed was untreated throughout the study and received reasonably uniform grazing use. Nevertheless, significant changes in some ground cover characteristics did occur between 1968 and 1981. Bare ground, cushion plant, and grass cover significantly decreased as did aerial sagebrush cover which declined about $30 \%$.

\section{Discussion and Conclusions}

Spraying Sane Creek watershed with 2,4-D increased forage available for livestock and improved soil surface conditions as measured by hydrologic cover. Improvement in hydrologic cover resulted primarily from an increase in litter cover and a reduction in bare soil. The differential effects of 2,4-D on grasses and broadleafed plants tended to be somewhat offsetting. Grass cover on the treated watershed increased after spraying in relation to the

Fig. 5. A snowmold fungus active on Loco Creek watershed in later years of study was effective in controlling mountain big sagebrush in areas of deep snow accumulation.

untreated watershed.

Total production of aboveground biomass on Sane Creek watershed was not changed by spraying compared to production on the untreated watershed, but vegetation composition was altered significantly. Grass production increased an average of $135 \%$ in the 5 years after spraying, and sagebrush production decreased $71 \%$, thus increasing the quantity of forage available for livestock. Because spraying occurred before most forb species were actively growing, it had little effect on forb productivity. Increased growth by grass plants present at the time of spraying was responsible for the large increase in grass production the year after treatment, rather than establishment of new plants. An additional 3 years were required for ground cover of grasses to similarly increase (Fig. 4). Hyder and Sneva (1956) also attributed the marked increase in grass production after sagebrush control primarily to vigorous growth by existing grass plants rather than enlargement of their basal area or establishment of new plants. Basal intercept of grasses was about a third greater 3 years after treatment in their study and most of the increase occurred the first year.

Sagebrush control within Sane Creek watershed was erratic. Complete kill of individual sagebrush plants ranged from $32 \%$ to $90 \%$ at individual primary sampling units. Sagebrush plants were at different phenological stages when sprayed because of differences in length of time required for snow to melt. Sagebrush on the east side of the watershed, where little snow accumulates, was a healthy green color, characteristic of sagebrush prior to twig elongation. Vegetation development was not nearly as advanced on the west side of the watershed, which is largely a snow depositional zone. However, sagebrush plants that had just emerged from the snowpack were as susceptible to the herbicide as plants in a vigorous growth stage. Neither were there readily apparent differences in mortality between the mountain and Wyoming subspecies of big sagebrush. The incomplete kill of sagebrush probably resulted from storage of the herbicide concentrate in an unheated warehouse the winter preceding treatment. Partial freezing of the concentrate at this time probably reduced its effectiveness.

Vigorous regrowth of partially killed sagebrush plants resulted in a rapid increase of sagebrush production on Sane Creek watershed in years after spraying. The effective treatment life will probably be shorter than if the degree of sagebrush control had been greater. Production of herbaceous matter by sagebrush was less then $100 \mathrm{~kg} /$ ha the first 2 years after spraying, but increased to 
244 and $199 \mathrm{~kg} / \mathrm{ha}$ in the fourth and fifth year after spraying, respectively (Table 3). The percentage contribution of grasses to the production total decreased in direct proportion to increasing sagebrush productivity (Fig. 3).

The decline of sagebrush cover on Loco Creek watershed between 1968 and 1981 was attributable primarily to a snowmold fungus that was first observed in 1973. Damage was especially severe between Loco Creek and the southern watershed boundary where snow accumulates in deep drifts (Fig. 5). The fungus develops on leaves and herbaceous stems while plants are snow-covered and a cottony-appearing mycelium covers infected branches when snow melts. The incidence of infection progressively increased as maximum snow depth increased from $40 \mathrm{~cm}$ to $120 \mathrm{~cm}$ (Sturges and Nelson 1986). Snowmold damage was confined to stands of mountain big sagebrush, because stands of Wyoming big sagebrush or black sagebrush were typically covered by less than $40 \mathrm{~cm}$ of snow.

\section{Literature Cited}

Blaisdell, J.P., and W.F. Mueggler. 1956. Effects of 2,4-D on forbs and shrubs associated with big sagebrush. J. Range Manage. 9:38-40.

Currie, P.O., M.J. Morris, and D.L. Neal. 1973. Uses and capabilities of electronic capacitance instruments for estimating standing herbage. Part 2. Sown Ranges. J. Br. Grass Soc. 28:155-160.

Green, R.H. 1979. Sampling design and statistical methods for environmental biologists. John Wiley \& Sons. New York.

Hedrick, D.W., D.N. Hyder, F.A. Sneva, and L.E. Poulton. 1966. Ecological response of sagebrush-grass range in central Oregon to mechanical and chemical removal of Artemisia. Ecology 47:432-439.

Hyder, D.N., and F.A. Sneva. 1956. Herbage response to sagebrush spraying. J. Range Manage. 9:34-38.

Juntunen, E.T., and L.A. Norris. 1972. Field application of herbicidesavoiding danger to fish. Spec. Rep. 354. Oregon Agr. Exp. Sta., Corvallis.

Kearl, W.G., and J.W. Freeburn. 1980. Economics of big sagebrush control for mitigating reductions of federal grazing permits. AE 80-05R. Div. Agr. Economics, Univ. of Wyoming, Laramie.

Laycock, W.A., and T.A. Phillips. 1968. Long-term effects of 2,4-D on lanceleaf rabbitbrush and associated species. J. Range Manage. 21:90-93.
Lusby, G.C. 1979. Effects of converting sagebrush cover to grass on the hydrology of small watersheds at Boco Mountain, Colorado. U.S. Geol. Surv. Water-Supply Paper 1532-J.

Miller, R.F., R.R. Findley, and J. Alderfer-Findley. 1980. Changes in mountain big sagebrush habitat types following spray release. J. Range Manage. 33:273-281.

Morris, M.J., K.L. Johnson, and D.L. Neal. 1976. Sampling shrub ranges with an electronic capacitance instrument. J. Range Manage. 29:78-81.

Nielsen, D.B. 1979. Economics and the sagebrush ecosystem. p. 237-251. In: The sagebrush ecosystem: a symposium. Utah State Univ., Logan.

Pechanec, J.F., A.P. Plummer, J.H. Robertson, and A.C. Hull, Jr. 1965. Sagebrush control on rangelands. USDA Agr. Handbook 277. Washington, D.C

Schmisseur, E., and R. Miller. 1980. Economics of spraying big sagebrush communities of eastern Oregon. Information Circular 686. Oregon Agr. Exp. Sta., Corvallis.

Schroeder, M.H., and D.L. Sturges. 1980 . Spraying of big sagebrush with 2,4-D causes negligible stream contamination. J. Range Manage. 33:311-312.

Schumaker, G.A., and C.L. Hanson. 1977. Herbage response after mechanical and herbicide treatment of big sagebrush in southwest Idaho. USDA Agr. Res. Serv., W-46.

Shown, L.M., G.C. Lusby, and F.A. Branson. 1972. Soil-moisture effects of conversion of sagebrush cover to bunchgrass cover. Water Resources Bull. 8:1265-1272.

Sturges, D.L. 1977. Soil moisture response to spraying big sagebrush: A seven-year study and literature interpretation. USDA Forest Serv. Res. Pap. RM-140. Rocky Mtn. Forest and Range Exp. Sta., Fort Collins, Colo.

Sturges, D.L., and D.L. Nelson. 1986. Snow depth and incidence of a snowmold disease on mountain big sagebrush. In: Wildland shrub symposium: the biology of Artemisia and Chrysothamnus. Provo, Utah. (In press).

Tabler, Ronald D. 1968. Soil moisture response to spraying big sagebrush with 2,4-D. J. Range Manage. 21:12-15.

Woodward, D.L., and F.L. Mayer, Jr. 1978. Toxicity of three herbicides (butyl, isooctyl, and propylene glycol butyl ether esters of 2,4-D) to cutthroat trout and lake trout. Tech. Paper 97. USDI Fish and Wildlife Serv., Washington, D.C. 